\title{
Determination And Characteristic Oil Biomarker of Illegal Crude Oil Production Using Mass Spectroscopy in Musi Banyuasin District
}

\author{
Edhi suryanto ${ }^{1}$, Sri Haryati² ${ }^{2}$ Budhi Kuswan ${ }^{3}$ \\ ${ }^{1}$ Mining technology department, technology faculty, Sriwijaya University \\ ${ }^{2}$ Chemistry Technology Department, Technology Faculty, Sriwijaya University \\ ${ }^{3}$ Geology Technology Department, Technology Faculty, Sriwijaya University
}

\begin{abstract}
South Sumatra is one of the largest petroleum producing provinces in Indonesia, especially in the region of Musi Banyuasin Petroleum resources other than legally cultivated by Pertamina as government representatives, but on the other hand the community also participate through Illegal Drilling activities. This study aims to determine the hydrocarbon content and characterization of petroleum produced illegally by communities in the Sangadesa, Babattoman and Keluang districts through the biomarker analysis of the distribution of n-Alkane C10-C34 (m/z: 57), pristane, phytane, sterane C27-C29 (m/z: 217,218,259) and specific biomarker using Gas Chromatography Mass Spectroscopy agilent GCMSD 6890/5973i with data analysis using MSD Chemstation F.01.01.2317 and Library Database NIST14. Petroleum samples taken from 10 illegal wells with a depth range of 80-250 meters and production period of 3 months until 3 years. Oil is produced through The illegal drilling is not the main oil source rock but the result of migration. Biomarkers Hydrocarbon analysis is one of the most widely used devices for exploration geochemistry, exploitation, production and forensic environment in the assessment and determination of sources of pollution related to petroleum material and derivatives very well.
\end{abstract}

Keyword ; Crude oil,illegal drilling,biomarker,GC/MS, caracterization

\begin{abstract}
Abstrak (Indonesian)
Sumatera Selatan salah satu propinsi penghasil minyak bumi terbesar di Indonesia, terutama di wilayah musi banyuasin. Sumber daya minyak bumi diusahakan secara legal oleh Pertamina, namun di sisi lain masyarakat turut mengelola melalui kegiatan Pengeboran Ilegal yang menjadi permasalah sosial ekonomi yang rumit satu dekade ini. Penelitian ini bertujuan untuk mengetahui kandungan biomarker hidrokarbon dan karakteristik minyak bumi yang dihasilkan secara tidak sah oleh masyarakat di kecamatan Sangadesa, Babattoman dan Keluang melalui analisis biomarker n-Alkana C10-C34 (m/ z: 57), pristane/phytane, sterane C27-C29 (m/z: 217,218,259) menggunakan Kromatografi Gas Mass Spektroskopi Agilent GCMSD 6890 / 5973i . Analisis data menggunakan MSD Chemstation F.01.01.2317 dan Library Database NIST14. Hasil penelitian meninjukan karakteristik distribusi biomarker hidrokarbon dalam sampel sampel minyak dari lokasi Babattoman dan Keluang biomarker n-Alkana C12 sampai C30 tidak ditemukan untuk menunjukkan bahwa minyak bumi memiliki biodegradasi moderat, sampel minyak dari Keban sedikit terdegradasi. Rasio $\mathrm{Pr} / \mathrm{Ph}, \mathrm{Pr} / \mathrm{nC} 17$, dan $\mathrm{Ph} / \mathrm{nC1}$ menunjukkan sumber bahan organik sumber laut yang tersimpan dalam kondisi lingkungan anoksik pengendapan. Rasio diasterane / steranes untuk ekstrak yang dianalisis dan sampel minyak menunjukkan rasio rendah $(0,09-0,23)$ menunjukkan batuan sumber penyimpan minyak berjenis batuan karbonat anoksik
\end{abstract}

Kata kunci ; Minyak bumi, pengeboran ilegal,biomarker, karakteristik

\section{Introduction}

Biological markers (biomarkers) are complex molecular fossils derived from biochemicals, particularly lipids, in once-living organisms. Because of the biological markers can be measured in both crude oils and extracts of petroleum source rocks, they provide a method to relate the two (correlation) and can be used by geolo-

\section{Article History:}

Received: 24 January 2018

Accepteed: 12 March 2018

DOI: $10.22135 /$ sje.2018.3.1.6-12

*Corresponding Author: lembu22sura@gmail.com gists to interpret the characteristics of petroleum source rocks when only oil samples are available. Biomarkers are also useful because they can provide information on the organic matter in the source rock (source), environmental conditions during its deposition and burial (diagenesis), the thermal maturity experienced by rock or oil (catagenesis), the degree of biodegradation, some aspects of source rock mineralogy (lithology), and age. [1,2]. Because of their general resistance to weathering, biodegradation, evaporation, and other processes, biomarkers are commonly retained as indicators of petroleum contamination in the environment. They also occur with certain human artifacts, such as bitumen sealant for ancient boats, hafting material on spears and arrows, burial preservatives, and as coatings for medieval paintings.

Biomarker and non-biomarker geochemical parameters are best used together to provide the most reliable geologic interpretations to help solve exploration, development, production, and environmental or archeological problems. Prior to biomarker work, 


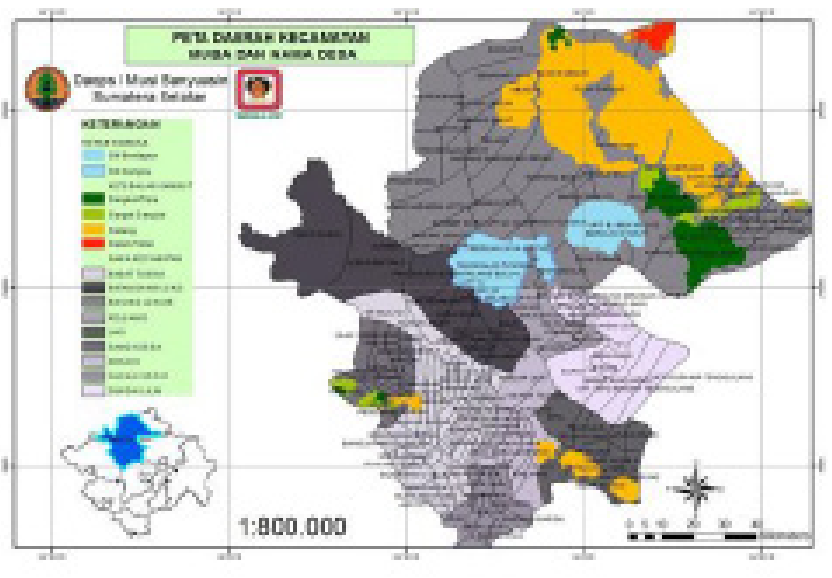

Figure. 1. Administrative map of Musi BanyuasinCountry

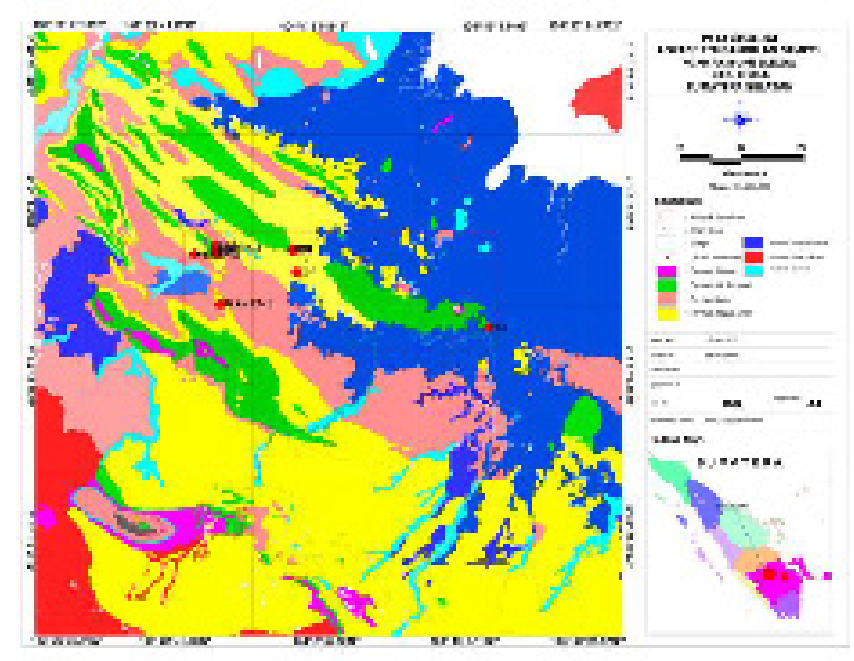

Figure. 2.Geological map of well location

oil and rock samples are typically screened using nonbiomarker analyses. The strength of biomarker parameters is that they provide more detailed information needed to answer questions about the source-rock depositional environment, thermal maturity, and the biodegradation of oils than non-biomarker analyses alone. Distributions of biomarkers can be used to correlate oils and extracts. For example,C27-C28-C29 steranes or monoaromatic steroids distinguish oil-source families with high precision. Cutting-edge analytical techniques, such as linked-scan gas chromatography/mass spectrometry/mass spectrometry (GC-MS/MS) provide sensitive measurements for correlation of light oils and condensates, where biomarkers are typically in low concentrations. Because biomarkers typically contain more than 20 carbon atoms, they are useful for interpreting the origin of the liquid fraction of crude oil, but they do not necessarily indicate the origin of associated gases or condensates[2].

Biomarkers can be used to determine source and maturity, even for biodegraded oils. Ranking systems are based on the relative loss of n-alkanes, acyclic isoprenoids, steranes, terpanes, and aromatic steroids during biodegradation.Biomarkers in oils provide information on the lithology of the source rock. For example, the absence of rearranged steranes can be used to indicate petroleum
Table 1. Illegal well location, and production periods

\begin{tabular}{ccccc}
\hline Well & Location & Depth (m) & $\begin{array}{c}\text { Production } \\
(\mathrm{bpd})\end{array}$ & Duration \\
\hline SA1 & Babat toman & 250 & 4 & 3 month \\
SA2 & Babat toman & 230 & 2 & 6 month \\
SA3 & Babat toman & 100 & 1 & $>3$ years \\
SA4 & Babat toman & 220 & 2 & 7 month \\
K1A & Keluang & 180 & 2 & 10 month \\
K1B & Keluang & 200 & 3 & 1 year \\
K2A & Keluang & 160 & 2 & 1 year \\
K2B & Keluang & 250 & 6 & 3 month \\
KB1 & Sanga desa & 180 & 1 & 1 years \\
KB2 & Sanga desa & 200 & 2 & 2 years \\
\hline
\end{tabular}

derived from clay-poor (usually carbonate) source rocks. Abundant gammacerane in some petroleum appears to be linked to a stratified water column (e.g. salinity stratification) during deposition of the source rock.

Biomarkers provide information on the age of the source rock for petroleum. Oleanane is a biomarker characteristic of angiosperms (flowering plants) found only in Tertiary and Upper Cretaceous rocks and oils[1]. Biomarker Groups are often used in petroleum analysis for the following interests:

Parameters of biomarkers related to age and rocks of petroleum resources for the study of correlation of oil-oil and oil-source rocks. Biomarkers group analyzed (1) alkanes and acyclic isoprenoids, (2) steranes and diasteranes, (3) terpanes and similar compounds, (4) aromatic steroids, hopanoids, and similar compounds, and (5) porphyrins

Parameters of biomarkers related to maturity of oil analyzed (1) alkanes and acyclic isoprenoids, (2) polycadinenes and related products, (3) steranes, (4) aromatic steroids, (5) aromatic hopanoids, and (6) porphyrine

\section{Experimental Section}

\subsection{Sampling Location and Collection}

Petroleum samples are derived from the production of illegal wells cultivated by the community in the sub-district of Babat Toman (2 wells), Keluang (4 wells) and Sangadesa (4 wells) Musi Banyuasindistrict. In all three locations found many illegal wells and has become a community industry. The samples are coded SA1, SA2, SA3, SA4, K1A, K1B, K2A, K2B, KB1 and KB2. The depth of the well, the period and the average amount of production are as shown in Table 1 and the geographic location can be seen in Figure 1.

\subsection{Sample Preparation}

The crude oil samples were prepared by first filtered to separate the impurities, and then taken $400 \mathrm{mg}$ added with $10 \mathrm{~mL}$-Hexane solvent. Crude oil in hexane solution was taken $200 \mathrm{uL}$ for extraction with SPE Extrelut NT3 Merck column, SPE column was firstly conditioned with absolute methanol for $10 \mathrm{~min}$. $200 \mathrm{uL}$ sample is applied to the SPE column and left for 10 minutes until all samples 7 
Table 2. The distribution of nC10-nC34, pristane and phytane

\begin{tabular}{|c|c|c|c|c|c|c|c|c|c|c|}
\hline \multirow[t]{2}{*}{ n-Alkana } & \multicolumn{10}{|c|}{ PERCENTAGE PEAK AREA } \\
\hline & SA1 & SA2 & SA3 & SA4 & K1A & K1B & K2A & K2B & KB1 & KB2 \\
\hline $\mathrm{C} 10 \mathrm{H} 22$ & 0.52 & ND & 0.68 & 0.28 & 0.07 & & 0.03 & 0.64 & 0.79 & 0.15 \\
\hline $\mathrm{C} 11 \mathrm{H} 24$ & 0.3 & ND & ND & ND & 0.22 & 0.13 & 0.33 & 0.79 & 1.24 & 1.14 \\
\hline $\mathrm{C} 12 \mathrm{H} 26$ & ND & 0.27 & ND & ND & ND & ND & ND & 0.84 & 1.24 & 1.2 \\
\hline $\mathrm{C} 13 \mathrm{H} 28$ & ND & 0.06 & ND & ND & ND & ND & ND & 1,04 & 0.35 & 0.26 \\
\hline $\mathrm{C} 14 \mathrm{H} 30$ & ND & ND & ND & ND & ND & 1.46 & ND & 1.29 & 1.63 & 1.76 \\
\hline C15H52 & ND & ND & ND & ND & ND & ND & ND & 1.45 & 1.64 & 1.75 \\
\hline C16H34 & ND & 0.19 & ND & ND & ND & 0.01 & ND & 1.55 & 2.05 & 1.94 \\
\hline C17H36 & ND & ND & ND & ND & ND & ND & ND & 1.58 & 1.67 & 1.73 \\
\hline C18H38 & ND & ND & ND & ND & ND & ND & ND & 1.41 & 1.33 & 1.5 \\
\hline PRISTANE & 0.89 & 0.44 & 0.33 & 0.56 & 0.18 & 0.82 & 0.26 & 0.8 & 1.28 & 1.82 \\
\hline $\mathrm{C} 19 \mathrm{H} 40$ & ND & ND & ND & ND & ND & ND & 0.58 & 0.33 & 0.32 & 1.53 \\
\hline PHYTANE & 0.98 & ND & ND & 0.78 & 0.98 & 0,72 & 0.71 & 0.23 & 0.71 & 0.84 \\
\hline $\mathrm{C} 2 \mathrm{OH} 42$ & ND & 0.41 & ND & ND & ND & ND & 0.47 & 0.13 & 0.51 & 1.04 \\
\hline $\mathrm{C} 21 \mathrm{H} 44$ & ND & ND & ND & ND & ND & ND & ND & 0.29 & 1.17 & 0.18 \\
\hline $\mathrm{C} 22 \mathrm{H} 46$ & ND & ND & ND & ND & 0.17 & ND & 0.39 & 0.3 & 1.08 & 0.15 \\
\hline $\mathrm{C} 23 \mathrm{H} 48$ & ND & ND & ND & ND & ND & 1.21 & ND & 0.35 & 0.18 & 0.17 \\
\hline $\mathrm{C} 24 \mathrm{H} 50$ & ND & ND & ND & ND & ND & 0.64 & ND & 1.36 & 0.94 & 0.94 \\
\hline $\mathrm{C} 25 \mathrm{H} 52$ & ND & ND & ND & ND & ND & ND & ND & 0.32 & 0.12 & 0.24 \\
\hline С26H54 & ND & ND & ND & ND & ND & ND & ND & 0.14 & 0.14 & 0.12 \\
\hline C28H56 & ND & ND & ND & ND & ND & ND & ND & ND & ND & 0.82 \\
\hline С29H60 & ND & ND & ND & ND & ND & ND & 0.31 & ND & 0.35 & 0.15 \\
\hline $\mathrm{C} 30 \mathrm{H} 62$ & ND & ND & ND & ND & ND & ND & ND & ND & ND & 0.66 \\
\hline C32H66 & ND & ND & ND & ND & ND & ND & ND & 0.46 & 0.15 & 0.51 \\
\hline C34H70 & ND & ND & ND & ND & ND & ND & ND & ND & ND & ND \\
\hline$>\mathrm{C} 34$ & ND & ND & ND & ND & ND & ND & ND & ND & ND & ND \\
\hline
\end{tabular}

Dichloromethane (1:1) as much as $5 \mathrm{ml}$ was added and accommodated filtrate. Elucidation is done with the same volume. Elute was concentrated to $1 \mathrm{ml}$ volume for later as sample on GC/MS

\subsection{Instrument and Sample analysis}

Separation and analysis of semi quantitative sample crude oil was performed using Agilent $6890 \mathrm{GC} / \mathrm{MS}$ Agilent interface analysis to an Agilent 5973i mass selective detector (MSD) in full scan mode. The Agilent Model 6890 was equipped with a DB-5MS coated capillary coulomn $(30 \mathrm{~m}$ x $0,25 \mathrm{~mm}$ ID x 0.25 um film thickness. The instrument were setting operational condition of oven with initial temperature $500 \mathrm{C}$,followed by increase temperature of $6^{\circ} \mathrm{C} / \mathrm{min}$ to $3250 \mathrm{C}$. The final gradien temperature was constant at $3250 \mathrm{C}$ for 2 min total run time $45.67 \mathrm{~min}$.

Chromatogram was analyzed by software MS Chemstation F.01.01.2317 and Library Database NIST14.The work involves:

1. Product screening and determining hydrocarbon group.

2. Fingerprinting and mathcing distribution patterns of target $n$-al kane and biomarker component.

3. Determination and comparison of diagnostic ratio biomarker
The biomarkers group identified semi qualitatively in this study were n-alkanes, isoprenoid pristane-phytane, regular sterane $\mathrm{C} 27-\mathrm{C} 29$, diasterane $\mathrm{C} 27-\mathrm{C} 29$ and hopane $\mathrm{C} 30$ based on the percent peak area of each compound from the total percent of all peaks area on the chromatogram.

\section{Result and Discussion}

\section{1. n-Alkana distribution}

Gas chromatograms of the saturated fractions from representative samples are shown in Figure 4 and Table 2. The chromatograms indicate that the aliphatic hydrocarbons are dominated by n-alkanes, C10-C30, while branched and cyclic alkanes are less important constituents. The presence of n-alkanes as the most abundant constituents in H-J which extends to $\mathrm{C} 30$ is indicative of no or low levels of biodegradation [1]. Chromatograms A-G in Figure 4 there is only n-alkanes $\mathrm{nC} 10$ - C11, pristane phytane and loses many other n-alkane fractions that indicate the petroleum undergoes severe biodegradation.

Gas chromatography fingerprints can indicate certain types of 
Suryanto et al. | Sriwijaya Journal of Environemnt, 3(1) 2018

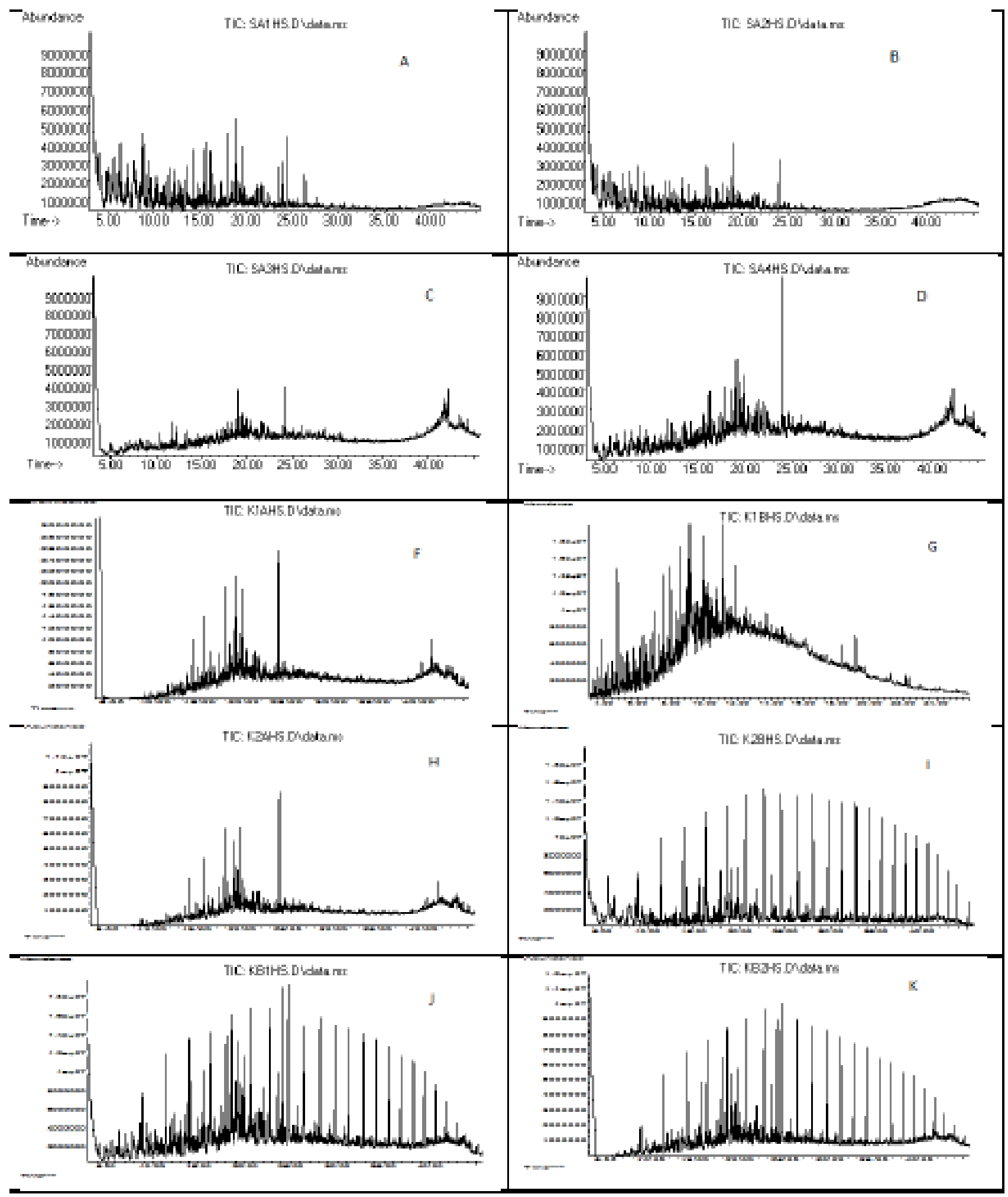

Figure.3. GCMS chromatogram of crude oil sample from Sungai Angit (A,B,C,D), Keluang (E,F,G,H) and Keban (I,J).

source organic matter input. Bimodal n-alkane distributions, and those skewed toward the range $\mathrm{nC} 23-\mathrm{nC} 31$, are usually associated with terrigenous higher-plant waxes. The C27, C29, and C30 of $\mathrm{Ph}$ (phytane), $\mathrm{Pr}$ (pristine), n-alkanes in crude oils and sourcerock extracts are originating mainly from higher-plant epicuticular waxes [7]. Acyclic alkanes with one or more sites of branching are notably abundant components of Archean, Proterozoic, and Early Paleozoic bitumen with most reported occurrences being low molecular weight (C14-C19) monomethylalkanes. Microbial mat communities, particularly those where cyanobacteria are the pre- 
Suryanto et al. | Sriwijaya Journal of Environemnt, 3(1) 2018

Table 3. The biomarker rasio of isoprenoid pristan,phytan,n-C17,n-C18

\begin{tabular}{|l|c|c|c|c|c|c|c|c|c|c|c|c|}
\hline Well & Depth(m) & Pri & Phy & nC17 & nC18 & Pri/Phy & $\begin{array}{c}\text { Pri/(Pri+- } \\
\text { Phy })\end{array}$ & Pr/nC17 & Phy/nC18 & (Pri+nC17) & Phy+nC18 & $\begin{array}{c}\text { (Pri+nC17)/ } \\
(\text { Phy+nC18) }\end{array}$ \\
\hline SA1 & 250 & 0,89 & 0,98 & 0,46 & 0,23 & 0,9082 & 0,4759 & 19,348 & 42,609 & 1,87 & 1,21 & 15,455 \\
\hline SA2 & 230 & 0,44 & 0,49 & 0,06 & 0 & 0,8980 & 0,4731 & 73,333 & 0 & 0,93 & 0,49 & 18,980 \\
\hline SA3 & 100 & 0,33 & 0 & 0 & 0,13 & 0,0000 & 10,000 & 0,0000 & 0 & 0,33 & 0,13 & 25,385 \\
\hline SA4 & 220 & 0,56 & 0,78 & 0 & 0 & 0,7179 & 0,4179 & 0,0000 & 0 & 1,34 & 0,78 & 17,179 \\
\hline K1A & 180 & 0,18 & 0,98 & 0,07 & 0,17 & 0,1837 & 0,1552 & 25,714 & 57,647 & 1,16 & 1,15 & 10,087 \\
\hline K1B & 200 & 0,82 & 0,72 & 0,84 & 0 & 11,389 & 0,5325 & 0,9762 & 0 & 1,54 & 0,72 & 21,389 \\
\hline K2A & 220 & 0,26 & 0,71 & 0,11 & 0,37 & 0,3662 & 0,2680 & 23,636 & 19,189 & 0,97 & 1,08 & 0,8981 \\
\hline K2B & 250 & 0,8 & 0,23 & 1,58 & 1,41 & 34,783 & 0,7767 & 0,5063 & 0,1631 & 1,03 & 1,64 & 0,6280 \\
\hline KB1 & 180 & 1,28 & 0,71 & 1,67 & 1,33 & 18,028 & 0,6432 & 0,7665 & 0,5338 & 1,99 & 2,04 & 0,9755 \\
\hline KB2 & 200 & 1,82 & 0,84 & 1,73 & 1,5 & 21,667 & 0,6842 & 10,520 & 0,56 & 2,66 & 2,34 & 11,368 \\
\hline
\end{tabular}

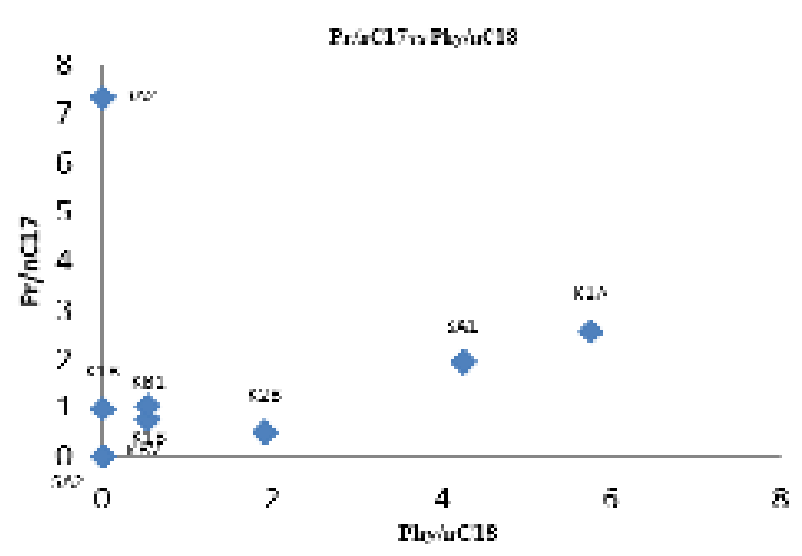

Figure.4. Pr/nC17 vs Phy/nC18 cross plot maturity level, source

of marine organic matter from petroleum analyzed

dominant organism, are well known for having high abundances and distinctive patterns of short-chain (C15-C20) methyl alkanes and are considered to be one of the major sources since these same hydrocarbons have been identified in cyanobacterial cultures [4,5]

The distribution of Alkyl Cyclohexanes, Cyclopentanes high-molecular weight homologs in the $\mathrm{C} 41$ to $\mathrm{C} 46$ range may be a useful tool to obtain information about the depositional environment A predominance of odd-over-even (OEP) carbon numbers in the above range seems to indicate petroleum from marine sources, while petroleum hydrocarbons with no distinct carbon number preference or a low even-over-odd (EOP) predominance might have a freshwater origin. A strong EOP of C41 to C46 alkylcyclopentanes may be a useful indicator for oils sourced from saline lake sediments. This compound group in crude oil sample are $\mathrm{Cy}$ clohexane, ethyl-Cyclohexane, 1,1,3-trimethyl- , Cyclopentane, 1,1,3-trimethyl[2].

Various irregular acyclic isoprenoids are important biomarkers. This compound and related highly branched isoprenoids originate from both marine; lacustrine phytoplanktonic algae and bacteria and may indicate hypersaline depositional conditions. Almost all of the petroleum samples SA1-KB2 found an unusual isoprenoid where there is a branching on atom $\mathrm{C} 7$ pentadecane atoms such as 2,6,10,14-Tetramethyl-7-(3-methylpent-4-enylidene) pentadecane is analogous to pristane $(2,6,10,14$-Tetramethyl) pentadecane [2].

\subsection{Pristane/Phytane ratio}

Pristane (C19) and phytane (C20) is the phytal side chain of chlorophyll (a) in phototrophic organisms and bacteriochlorophyll (a) and (b) in purple sulphur bacteria [2]. Reducing or anoxic conditions in sediments promote cleavage of the phytal side chain to yield phytol, which undergoes reduction to dehydrophytal and phytane. Oxic conditions promote the competing conversion of phytol to pristine by oxidation of phytol to phytenic acid, decarboxylation to pristene and then reduction to pristane [1].

Interpreted the redox conditions of the source rock depositional environment for crude oil are based on a model for the origin of pristane $(\mathrm{Pr})$ and $(\mathrm{Ph})$ phytane. According to many authors, $\mathrm{Pr} / \mathrm{Ph}$ less than 1 in crude oil indicates anoxic source rock deposition, particularly when accompanied by high porphyrin and sulphur contents, while $\mathrm{Pr} / \mathrm{Ph}$ more than 1 indicates oxic deposition. $\mathrm{Pr} / \mathrm{Ph}$ is commonly applied because $\mathrm{Pr}$ and $\mathrm{Ph}$ are measured easily using gas chromatography.

The presence of the regular isoprenoids pristane (Pr) and phytane $(\mathrm{Ph})$ in crude oils and coal extracts to propose a mechanism for the production of relatively high concentrations of pristine in oxic type environments and high concentration of phytane in reducing type environments. Thus, the $\mathrm{Pr} / \mathrm{Ph}$ ratio evolved as an indicator of the oxicity of the depositional environment. [3].

Table 3 showed the $\mathrm{Pr} / \mathrm{Ph}$ ratios in the range of $0.183-3.478$ are interpreted to indicate specific pale environmental conditions without collaborating data. $\mathrm{Pr} / \mathrm{Ph}$ more than 3.0 indicates terrigenous plant input deposited under oxic to suboxic conditions, while $\mathrm{Pr} / \mathrm{Ph}$ less than 0.8 indicates saline to hypersaline conditions associated with evaporate and carbonate deposition [2].

An oil accumulation have pristane/phytane ratio more than 3.0, indicative of a predominantly non marine source from terrestrial organic matter. Furthermore, the progressive change from waxy to light oil has been interpreted to indicate an increased contribution of bacterial or algal source inputs to the lighter oil An alternative interpretation is that the original source input, although dominated from terrestrial organic matter, has been masked by secondary alteration processes. [5]

The result of petroleum analysis on Pristane/Phytane ratio of ten oil samples was one sample not found phytane in SA3 sample. SA3 wells have been in operation for more than 3 years and are nearing the end of production. The ratio of Pristane / Phytane ratio in all samples was $0-3.47$. The value of pri/phy $<1$ or on other biomarker parameters pri / phy $<2$ indicates that oil is formed in 
Table.4. Percentage of area sterane, diasteran, hopane and diagnostic ratio

\begin{tabular}{|c|c|c|c|c|c|c|c|c|c|c|c|c|c|c|c|}
\hline \multirow[t]{2}{*}{ Well } & \multirow[t]{2}{*}{ Depth(m) } & \multicolumn{3}{|c|}{ sterane (m/z 217) } & \multirow{2}{*}{$\begin{array}{c}\text { Str } \\
\text { Total }\end{array}$} & \multicolumn{3}{|c|}{ Diasterane (m/z 218) } & \multirow{2}{*}{$\begin{array}{c}\text { Dia } \\
\text { total }\end{array}$} & \multirow{2}{*}{\begin{tabular}{|c|} 
hopane \\
C30
\end{tabular}} & \multirow{2}{*}{$\begin{array}{l}\text { Str/ } \\
\text { Dia }\end{array}$} & \multirow{2}{*}{$\begin{array}{c}\mathrm{C} 27 / \\
\mathrm{C} 29 \mathrm{~S}\end{array}$} & \multirow{2}{*}{$\begin{array}{l}\text { C27/ } \\
\text { C29 } \\
\text { Dia }\end{array}$} & \multirow{2}{*}{$\begin{array}{c}\text { C27D/ } \\
\text { (Str+ } \\
\text { Dia) }\end{array}$} & \multirow{2}{*}{$\begin{array}{c}\text { Str/ } \\
\text { Hopane }\end{array}$} \\
\hline & & $\mathrm{C27}$ & $\mathrm{C28}$ & $\mathrm{C29}$ & & $\mathrm{C27}$ & $\mathrm{C28}$ & $\mathrm{C29}$ & & & & & & & \\
\hline SA1 & 250 & 0 & 0 & 0,37 & 0,37 & 0,36 & 0,25 & 0,61 & 1,22 & 0,87 & 0,3033 & 0 & 0,5902 & 0,22642 & 0,4253 \\
\hline SA2 & 230 & 0 & 0,29 & 0,35 & 0,64 & 0,45 & 0,63 & 0,8 & 1,88 & 0,98 & 0,3404 & 0 & 0,5625 & 0,17857 & 0,6531 \\
\hline SA3 & 100 & 0,04 & 0,53 & 0,86 & 1,43 & 0,06 & 0,53 & 0,86 & 1,45 & 0,54 & 0,9862 & 0,0465 & 0,0698 & 0,02083 & 26,481 \\
\hline SA4 & 220 & 0,03 & 0,2 & 0,33 & 0,56 & 0,12 & 0,2 & 0,33 & 0,65 & 0,05 & 0,8615 & 0,0909 & 0,3636 & 0,09917 & 11,2 \\
\hline $\mathrm{K} 1 \mathrm{~A}$ & 180 & 0,16 & 0,33 & 0,64 & 1,13 & 0,24 & 0,33 & 0,64 & 1,21 & 0,11 & 0,9339 & 0,25 & 0,375 & 0,10256 & 102,727 \\
\hline K1B & 200 & 0,36 & 0,14 & 0,25 & 0,75 & 0,34 & 0,44 & 0,03 & 0,81 & 0,3 & 0,9259 & 1,44 & 11,333 & 0,21795 & 2,5 \\
\hline $\mathrm{K} 2 \mathrm{~A}$ & 220 & 0,41 & 0,4 & 0,26 & 1,07 & 0,31 & 0,23 & 0,4 & 0,94 & 0,39 & 11,383 & 15,769 & 0,775 & 0,15423 & 27,436 \\
\hline $\mathrm{K} 2 \mathrm{~B}$ & 250 & 0,41 & 0,28 & 0,53 & 1,22 & 0,28 & 0,28 & 0 & 0,56 & 0 & 21,786 & 0,7736 & 0 & 0,15730 & 0 \\
\hline KB1 & 180 & 0,17 & 0,08 & 0,22 & 0,47 & 0,17 & 0,08 & 0,05 & 0,3 & 0,11 & 15,667 & 0,7727 & 3,4 & 0,22078 & 42,727 \\
\hline KB2 & 200 & 0 & 0,11 & \begin{tabular}{|l|}
0,27 \\
\end{tabular} & 0,38 & 0,19 & 0,13 & 0,28 & 0,6 & 0,12 & 0,6333 & 0 & 0,6786 & 0,19388 & 31,667 \\
\hline
\end{tabular}

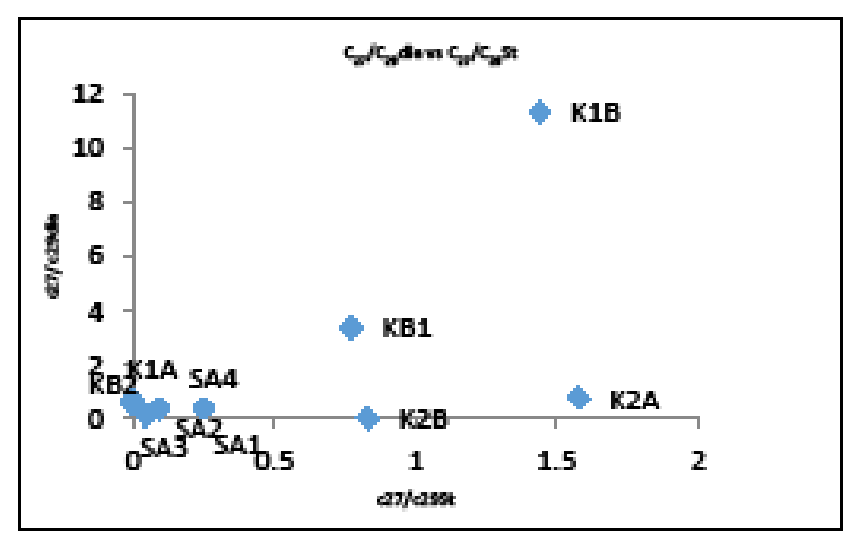

Figure.5. C27/C29dia vs C27/C29St showed dispositional environment

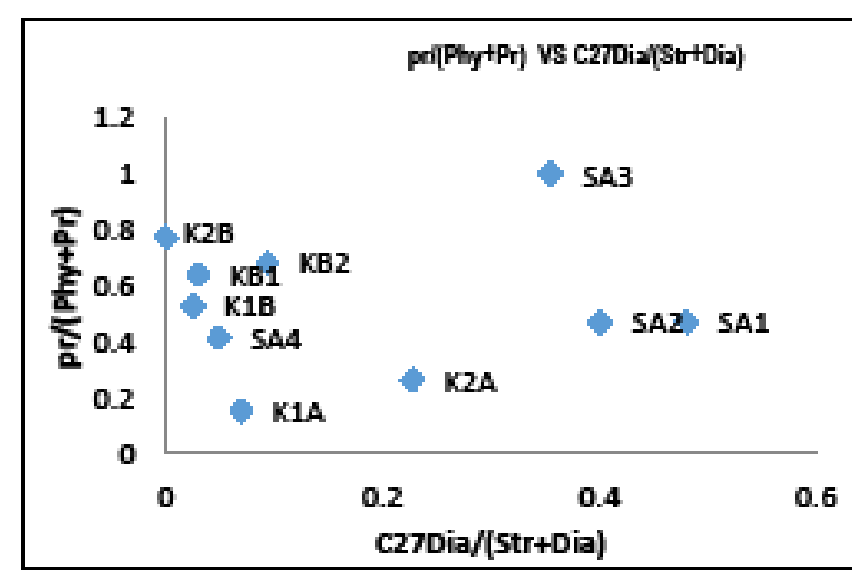

Figure 6. Pr /(Pr+Phy) vs C27DIA/(STR+DIA) cross plot enviroment anoxic source rock and anoxic shale marine source organic mater

the anoxic deposition environment. If the value of pri / phy> 3 as in the K2B sample cannot be directly stated that the oil comes from a terrestrial organism because at other not too distant samples such as K1A, K1B and K2A the ratio of pri / phy $<2$ as seen in Table 4.

Pristane/nC17 and phytane/nC18 are sometimes used in petroleum correlation studies. The oils from rocks deposited under open-water conditions showed $\operatorname{Pr} / \mathrm{nC} 17<0.5$, while those from in- land peat swamps had ratios greater than 1 . These ratios should be used with caution for several reasons. Both $\mathrm{Pr} / \mathrm{nC} 17$ and $\mathrm{Ph} / \mathrm{nC} 18$ decrease with thermal maturity of petroleum. The other ratio like of the ratio $(\mathrm{Pr}+\mathrm{nC} 17) /(\mathrm{Ph}+\mathrm{nC} 18)$ because it is less affected by variations in thermal maturity than $\mathrm{Pr} / \mathrm{nC} 17$ or $\mathrm{Ph} / \mathrm{nC} 18$. Biodegradation increases these ratios because aerobic bacteria generally attack the n-alkanes before the isoprenoids. [3]

\subsection{Diasterane/Sterane}

Diasteranes/steranes ratios are commonly used to distinguish petroleum from carbonate versus clastic source rocks [1]. Low diasteranes/steranes ratios $(\mathrm{m} / \mathrm{z} 217)$ in oils indicate anoxic clay-poor or carbonate source rocks. During diagenesis of these carbonate sediments, bacterial activity provides bicarbonate and ammonium ions, resulting in increased water alkalinity. Under these conditions of high $\mathrm{pH}$ and low Eh, calcite tends to precipitate and organic matter preservation is improved [2]. High diasteranes/steranes ratios are typical of petroleum derived from clay-rich source rocks and in some crude oils can result from high thermal maturity and/or heavy biodegradation [2]

At high levels of thermal maturity, rearrangement of steroids to diasterane precursors may become possible, even without clays, due to hydrogen-exchange reactions, which are enhanced by the presence of water. Alternatively, diasteranes simply may more stable and survive thermal degradation better than steranes. The diasteranes/steranes ratio is useful for distinguishing source-rock depositional conditions only when samples show comparable levels of thermal maturity [2][6].

Heavy biodegradation can result in selective destruction of steranes relative to diasteranes. However, it's possible that non-biodegraded oil might mix with heavily biodegraded oil showing a much higher diasteranes/steranes ratio. In such cases, only careful quantitative assessment of each biodegradation-sensitive parameter can led to the correct interpretation [1]

The diasteranes/steranes ratio for the analyzed extracts and oil samples shows generally low ratios $(0.09-0.23)$ (table 4$)$ indicating anoxic carbonate source rocks.

There is a positive correlation between $\mathrm{Pr} /(\mathrm{Pr}+\mathrm{Ph})$ and $\mathrm{C} 27 \mathrm{di}-$ asteranes/ (diasteranes+steranes) that were controlled by the depositional environments [5]. $\mathrm{Pr} /(\mathrm{Pr}+\mathrm{Ph})$ increases with clay content, as measured by increasing diasteranes, which parallels oxidative strength of the water column during deposition.

The cross plot of C27 / C29 diasterane versus C27 / C29 sterane 
used to identify the source of the analyzed extracts and oil samples in this study .The result of this cross plot indicated a mixed origin of organic matters, and all the extracts and the eight oil samples have generally C27 / C29 diasterane values larger than C27/C29 sterane.

\section{Conclusion}

The GC/MSD analysis for extracts from selected crude oil samples from Babat Toman, Keluang and Sangadesa sub district indicated a euxinic, marine (to mix) carbonate source of deposition.

Characteristics of the distribution of the alkane biomarkers in the samples gave results that oil samples from the Babattoman and Keluang locations specifically for the nAlkana C12 to C30 biomarkers were not found to indicate that petroleum had moderate biodegradation, the oil samples from Keban were mildly degraded.

$\mathrm{Pr} / \mathrm{Ph}, \mathrm{Pr} / \mathrm{nC} 17$, and $\mathrm{Ph} / \mathrm{nC} 18$ ratios indicate marine source organic matters deposited in the anoxic deposition environment condition

The diasteranes / steranes ratio for the analyzed extracts and oil samples show generally low ratios $(0.09-0.23)$ indicating anoxic carbonate source rocks.

\section{Acknowledgements}

The authors acknowledge the collaboration and support provided by Forensic Laboratory of Indonesian National Police and Mining technology department of Sriwijaya University. They are also grateful for the critical and constructive reviews of the anonymous reviewers.

\section{Reference}

[1] K.E. Peters, J.M. Moldowan, The Biomarker Guide vol.1,2nd edition Prentice Hall, Englewood Cliffs, NJ, 2005.

[2] K.E. Peters, J.M. Moldowan, The Biomarker Guide vol.2, 2nd edition Prentice Hall, Englewood Cliffs, NJ, 2005

[3] Broock, J.J., and Summons, R.E., 2004, Sedimentary Hydrocarbons, Biomarkers for Early Life, in Holland, H.D. and Turekian, K.K. (eds.), Treatise on Geochemistry, Vol. 8, Biogeochemistry, Elsevier, Amsterdam, $425 \mathrm{P}$.

[4] Jassim S. Z. and Buday T., 2006, Late Toarcian-Early Tithonian (Mid-Late Jurassic) Megasequence AP7, Chapter 10, in Jassim, S.Z., and Goff, J.C. (Eds.), Geology of Iraq,

[5] Riosuji, L.C., and Antia, B.C., 2005, Geochemical Implication of some Chemical Fossils as Indicators of Petroleum Source Rocks, AAPL Journal, Sci. Environ. Mgt. Vol. 9, No.

[6] Younes, .M.A., and Philp, .R.P., 2005, Source Rock Characterization based on Biological Marker Distribution of Crude Oils in the Southern Gulf of Suez, Egypt, Journal of Petroleum Geology, Vol. 28 No. 3

[7] Schlesinger,J.W, 2003, Biogeochemistry, Royal Holloway, University of London, Egham, UK 